\title{
How calculating the true volume of blood loss on the background of the physiological loss of liquids in practice
}

\author{
Andrey Belousov $^{1 *}$, Elena Malygon ${ }^{2}$ and Vadim Yavorskiy ${ }^{3}$ \\ ${ }^{1}$ Laboratory of Applied Nanotechnology of Belousov, Kharkov Medical Academy of Postgraduate Education, Ukraine \\ ${ }^{2}$ Deputy Director of the Medical Department of the Ministry of Health of Ukraine \\ ${ }^{3}$ Kharkiv Regional Center of Blood Service
}

\begin{abstract}
In conditions of acute blood loss, on the basis of calculations of the volume of blood loss and deficit of circulating blood volume the medical practitioner must to quickly assess the patient's condition, to assign optimum, adequate, and most importantly - a timely infusion-transfusion therapy that aimed at rapid elimination of circulatory hypoxia, prevention of coagulopathy. In the case when in the bleeding time was conducted infusion therapy, especially during surgical intervention on the background of the physiological loss of liquids, the calculation of the true volume of blood loss needs to be calculating in according to Belousov's formulas.
\end{abstract}

The need to use objective methods (formulas and calculations) to adequately assess the patient's condition, treatment blood loss based on clinical, physiological, pathophysiological and biochemical mechanisms [1].

The obvious fact is that for adequate evaluation of blood loss must be properly and objectively calculate its volume. Rationale the transfusion of erythrocytes on the basis of only the clinical laboratory test the patient's blood in conditions of iron deficiency, hypoplastic or aplastic anemia are false and dangerous. Acute blood loss leads to the development of the patient, primarily circulatory and not hemic hypoxia. Therefore, the severity of the patient with acute blood loss is not so much the deficiency of oxygen carrier, as deficient circulating blood volume (CBV).

Should also know that defined volume of blood loss never corresponds of deficit estimation of circulating blood volume (CBVdef.). For example, estimating blood loss is complicated by several factors, including urinary losses and the development of tissue edema [2]. Therefore, for calculation of CBVdef. is needed determining the volume of infusion solutions for the correction of blood loss.

In addition, the severity of the patient also depends on the state of compensatory mechanisms and the functional reserve of the all interested systems of organism. The conditions directly related to the condition of water balance. The ability to objectively assess adequately and quickly adjust the water balance - the key of pathogenetic efficacy treatment of acute blood loss.

Another important indicator of the treatment of acute blood loss - colloid osmotic pressure of blood (COPB). The balance of the water sectors between the vessels, tissues and cells depends on the COPB [3]. Evaluation of $\mathrm{pH}, \mathrm{PaO}_{2}, \mathrm{PaCO}_{2}, \mathrm{SpO}_{2}$, and status of buffer systems of blood is very important for correction of permeability of the cells. Status of buffer systems of the blood determines affinity between $\mathrm{Hb}$ and $\mathrm{O}_{2}$, creating the conditions for dissociation of $\mathrm{HbO}_{2}$ according to the effect Verigo-Bora.

The actual definition of the indicator of systemic transport oxygen
$\left(\mathrm{CTO}_{2}\right)$, no doubt, is of great diagnostic value. But, in conditions of acute blood loss more significant figure is the deficit VCB. Even if the result of the blood transfusions in the clinical analysis of the blood to will increase the level of hemoglobin (the main carrier of oxygen), it does not mean that the indicators of consumption and the index of utilization of oxygen to tissues also will increase. This is primarily due to the fact that in terms of centralization of blood flow, compensatory vasospasm consumption of oxygen to tissues is significantly reduced or stops altogether due to the inability of penetration of the erythrocytes in the capillaries which have spasm [4].

In addition, in conditions of metabolic acidosis, which occurs as a result of a circular hypoxia, a compensatory process activated dissociation of oxyhemoglobin and increases the amount of circulating free hemoglobin. The free hemoglobin in the capillaries of the lungs not associating with oxygen due to compensatory performs a buffer function.

Thus, calculation of the indicator of systemic transport oxygen $\left(\mathrm{STO}_{2}\right)$ in acute bleeding has not practical value. The calculation of consumption indicators of oxygen, the index utilization of oxygen to tissues, data artery-venous difference on oxygen, in this case, it is not advisable to recommend. This is primarily due to the accumulation of mathematical calculations and of small practical significance of the data [5]

In conditions of acute blood loss, on the basis of calculations of the volume of blood loss and deficit of circulating blood volume the medical practitioner must to quickly assess the patient's condition, to

Correspondence to: Andrey Belousov, Laboratory of Applied Nanotechnology of Belousov, Kharkov Medical Academy of Postgraduate Education, Ukraine, E-mail: an.belousov2012@yandex.ua

Key words: acute blood loss; infusion-transfusion therapy; Belousov's formulas.

Received: December 01, 2017; Accepted: January 24, 2018; Published: January 26,2018 
assign optimum, adequate, and most importantly - a timely infusiontransfusion therapy that aimed at rapid elimination of circulatory hypoxia, prevention of coagulopathy.

In the case when in the bleeding time was conducted infusion therapy, especially during surgical intervention on the background of the physiological loss of liquids, the calculation of the true volume of blood loss needs to be calculating in according to Belousov's formulas:

$$
V_{\text {true blood }}=V B S_{\text {af/surg. }} \times \frac{\left(H b_{\text {a/inf.proper }}-H b_{\text {af } / \text { surg. }}\right)}{H b_{\text {af } / \text { surg. }}}
$$

Note: \begin{tabular}{|l|l|}
$\mathrm{V}_{\text {true blood. }}$ & $\begin{array}{l}\text {-true volume of blood loss }(\mathrm{L}) ; \\
\text {-volume circulation of blood after the surgery, } \\
\text { which calculates by Sidor's method }(\mathrm{L}) ;\end{array}$ \\
$\mathrm{Hb}_{\text {af/surg. }}$ & $\begin{array}{l}\text {-proper concentration of } \mathrm{Hb} \text { in the peripheral } \\
\text { venous blood of the patient after infusion }(\mathrm{g} / \mathrm{l}) ; \\
\text {-concentration of } \mathrm{Hb} \text { in the peripheral venous } \\
\text { blood of the patient after surgery, which is } \\
\text { determined during surgery or after stopping the } \\
\text { bleeding and stabilize of hemodynamic }(\mathrm{g} / \mathrm{l}) .\end{array}$ \\
\hline $\mathrm{Hb}_{\text {af/surg. }}$
\end{tabular}

$$
\mathrm{Hb}_{\mathrm{af} / \text { inf.proper }}=\mathrm{Hb}_{\text {intial }}-\left(0,5 K \times \mathrm{Hb}_{\text {intial }}\right)
$$

\begin{tabular}{|c|c|c|}
\hline Note: & $\begin{array}{l}K \\
H b_{\text {af./inf }} \\
H b_{\text {initial }}\end{array}$ & $\begin{array}{l}\text { - coefficient of volume balance; } \\
\text { - proper concentration of } \mathrm{Hb} \text { in the peripheral } \\
\text { venous blood of the patient after infusion }(\mathrm{g} / \mathrm{l}) \text {; } \\
\text { - initial concentration of } \mathrm{Hb} \text { in the peripheral venous } \\
\text { blood of the patient }(\mathrm{g} / \mathrm{l}) \text {; }\end{array}$ \\
\hline
\end{tabular}

$$
\mathrm{K}=\frac{\text { Vinf. }-(\mathrm{V} \text { diuresis }+\mathrm{V} \text { physiological loss of sectors of liquid })}{\mathrm{VBC} \text { actual }}
$$

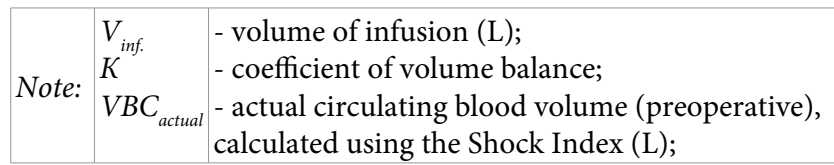

\section{Example of calculation:}

A patient with a body weight of $70 \mathrm{~kg}$.

Data before surgery: blood pressure $(\mathrm{BP})=100 / 60 \mathrm{~mm} \mathrm{Hg}$.; heart rate $=80$ beats $/ \mathrm{min}, \mathrm{Hb}=105 \mathrm{~g} / \mathrm{l}$.

Data after intervention: volume of infusion $=2,0 \mathrm{~L}$, a fixed urine output $=150 \mathrm{ml}, \mathrm{BP}=90 / 70 \mathrm{~mm}$. Hg., heart rate $=84$ beats $/ \mathrm{min}$., the concentration of $\mathrm{Hb}=68 \mathrm{~g} / \mathrm{l}$, hematocrit $(\mathrm{Ht})=0.23$.

The physician should answer two main questions:

1. What volume of blood loss during surgery?

2. Do need a blood transfusion?

Calculating the necessary ancillary data:

Part weight of hematocrit after surgery is 17.7.

The circulating of blood volume after surgery, calculated by Sidor's method is $3.95 \mathrm{~L}$.

Calculation: the actual circulating of blood volume $=$ proper $C B V$ $(70 * 70=4.9 \mathrm{~L})$ - deficit $C B V$ (in accordance with the Shock Index).

Shock Index before surgery of 0.8 , which corresponds to a deficit volume (deficit CBV) of $0.5 \mathrm{~L}$. Hence, the actual $C B V=4.9 L-0.5 \mathrm{~L}$ $=4.4 \mathrm{~L}$.
If this is the case use a modified formula of Moore, the volume of blood loss $=1.55 \mathrm{~L}$. However, this calculation is not objective because it does not account for the volume of infusion and urine output during the operation.

Therefore, for an objective assessment of the true blood loss it is necessary to use the method of A.N. Belousov, which takes into account the volume of infusion and urine output:

Calculating the coefficient of volumetric balance:

$$
\mathrm{K}=\frac{(2-0.15)}{4.4}=0.42
$$

Calculating proper concentration of $\mathrm{Hb}$ in the peripheral venous blood of the patient after infusion:

$$
\mathrm{Hb} \text { after infus. }=105-(0.5 * 0.42 * 105)=83 \mathrm{~g} / l
$$

Calculating true volume of blood loss:

$$
\mathrm{V} \text { true blood }=3.95 * \frac{(83-68)}{68}=0.87 \mathrm{~L}
$$

\section{Conclusion}

Consequently, due to the hemodilution the concentration of $\mathrm{Hb}$ in the blood of patients was decreased by $22 \mathrm{~g} / \mathrm{l}$, as a result of blood loss only $15 \mathrm{~g} / \mathrm{l}$. Objective calculation of the true volume of blood loss was $870 \mathrm{ml}$ or $15 \%$ of VBC, which corresponds to a blood loss of degree I (in according to classification of Marino). Despite the concentration of hemoglobin after the surgery which was $68 \mathrm{~g} / \mathrm{l}$, indication for transfusion of red blood cells has not. Moreover, in case of ignore of the fact and unreasonable transfusion of red blood cells, there is a direct threat of development after transfusion complications - volume overload.

\section{References}

1. Pope A, French G, Longnecker DE (1999) Fluid Resuscitation: State of the Science for Treating Combat Casualties and Civilian Injuries. Institute of Medicine (US) Committee on Fluid Resuscitation for Combat Casualties. Washington (DC): National Academies Press (US).

2. Gutierrez H, David Reines, Marian E (2004) Wulf-Gutierrez. Clinical review: Hemorrhagic shock. J Crit Care 8: 373-381.

3. Morissette MP (1977) Colloid osmotic pressure: its measurement and clinical value Can Med Assoc J 116: 897-900.

4. Polivoy VP (2016) Correction of hypovolemia. Clinical Transfusiology III of Part. The Chernivtsi Medical University p. 448.

5. Polivoy VP (2017) Legal aspects of hemotransfusion. Clinical Transfusiology. IV of Part. The Chernivtsi Medical University, p. 324.
Copyright: (C2018 Jiaxuan Du. This is an open-access article distributed under the terms of the Creative Commons Attribution License, which permits unrestricted use, distribution, and reproduction in any medium, provided the original author and source are credited. 